Available online at http://jurnal.goretanpena.com/index.php/JSSR

\title{
PERSPEKTIF KAJIAN AKSIOLOGI PADA PEMBELAJARAN DARING DI ERA PANDEMIC
}

\author{
Anim $^{1,2}$, Dian Armanto ${ }^{1}$, Nilam Sari ${ }^{1,3}$ \\ ${ }^{1}$ Pascasarjana Pendidikan Matematika, Universitas Negeri Medan \\ ${ }^{2}$ Pendidikan Matematika, Universitas Asahan \\ ${ }^{3}$ Pendidikan Matematika, Universitas Quality Medan \\ Email: ${ }^{1}$ animfaqot30031991@ gmail.com, ${ }^{2}$ dianarmanto@unimed.ac.id, \\ 3nilamsarie@gmail.com
}

\begin{abstract}
Technological progress should contribute many benefits to human welfare, especially in the education aspect. In the pandemic era, teachers are forced to be technology literate by implementing online learning. However, in reality, the use of technology in online learning becomes an obstacle because optimal learning is not achieved specifically as the government hopes. This study discusses the analysis of axiology in online learning and uses the analysis method of literature review (literature research) from several relevant sources. The purpose of this article is to provide additional knowledge and learning for teachers so that later in the education unit they are able to actualize their abilities to produce competent students according to the expectations of the nation. The results of the literature study show that online learning does not support the achievement of learning aspects when viewed in axiological studies related to ethical and aesthetic values. Students still have difficulties and have problems in online learning so that they have not given birth to personal learning motivation and lack the creativity to develop the knowledge that has been obtained from teachers through online Learning.

Keyword: Axiology, technology, online learning
\end{abstract}

\begin{abstract}
Abstrak: Kemajuan teknologi seharusnya menyumbangkan banyak manfaat untuk kesejahteraan manusia khususnya pada aspek pendidikan. Di era pandemic memaksa guru untuk melek teknologi dengan di terapkannya pembelajaran daring. Namun kenyataannya dalam penggunaan teknologi pada pembelajaran daring menjadi penghambat karena tidak tercapainya pembelajaran dengan optimal secara khusus seperti harapan pemerintah.Penelitian ini membahas tentang analisis Aksiologi dalam pembelajaran daring dan menggunakan metode analisis kajian pustaka (literatur research) dari beberapa sumber yang relevan. Tujuan artikel ini adalah untuk memberi penambahan pengetahuan dan pembelajaran bagi guru agar nantinya ketika di satuan pendidikan mampu mengaktualisasikan kemampuan yang dimilikinya untuk menghasilkan peserta didik yang berkompeten sesui harapan bangsa.Hasil dari studi literature menunjukkan bahwa pembelajaran daring kurang mendukung tercapainya aspek pembelajaran jika dilihat dalam kajian aksiologi yang berkaitan dengan nilai etika dan estetika.Peserta didik masih kesulitan dan memiliki permasalahan dalam pembelajaran daring sehingga belum melahirkan motivasi belajar pribadi dan kurang memiliki kreatifitas untuk mengembangkan ilmu pengetahuan yang sudah didapat dari guru melalui pembelajaran daring.
\end{abstract}

Kata Kunci: Aksiologi, Teknologi, Pembelajaran Daring.

\section{PENDAHULUAN}

Di awal tahun 2020 seluruh aspek pendidikan mulai mengubah pola pengajaran dari tatap muka menjadi pola pengajaran daring.Hal ini disebabkan munculnya wabah virus Corona.Organisasi Kesehatan Dunia (WHO) menyatakan
COVID-19 darurat global yang pada tanggal 30 Januari2020 dan pandemi global pada 11 Maret2020. Saat ini, COVID-19 memengaruhi 213 negara dan wilayah (WHO, 2020) Di Indonesia sendiri, pemerintah telah membatasi mobilisasi masyarakat dalam upaya untuk mencegah 
Available online at http://jurnal.goretanpena.com/index.php/JSSR

penyebaran penyakit dan tetap mengedepankan agenda: bekerja dari rumah, belajar dari rumah dan beribadah di rumah.(Almanthari et al., 2020). Istilah belajar dari rumah sering disebut sebagai pembelajaran daring, dan penerapan pembelajaran daring ditujukan pada semua jenjang pendidikan dari TK sampai jenjang pergururuan tinggi(Anim \& Mapilindo, 2020). Alternatif solusi yang dipilih berkorelasi dengan berkembangnya revolusi industry 4.0 yang sangat berpengaruh pada terlaksananya pembelajaran daring.

Namun perkembangan IPTEK tidak selamanya memberi keuntungan bagi peserta didik.Kenyataan yang terlihat adanya kendala yang menyebabkan persoalan baru dengan kecenderungan penurunan kemampuan belajar peserta didik. Fakta yang menunjukkan hal yang berbeda sejak pembelajaran berubah menjadi pembelajaran daring secara masal sehingga memberi dampak terhadap menurunnya belajar dan motivasi belajarpeserta didik pada pembelajaran matematika(Theopilus et al., 2020).

Motivasi merupakan hasrat dan hal penting bagi seseorang agar mampu melaksanakan suatu kegiatan tertentu sehingga semangat dalam bekerja atau belajar semakin bertambah (Sosial \& Sulistyawati, 2020). Artinya, secara tidak langsung siswa dengan motivasi belajar tinggi akan terdorong melakukan berbagai macam aktivitas belajar guna menggapai tujuan yang dikehendakinya. Hal ini dikarenakan makin besar motivasi siswa, maka makin besar juga keinginan siswa untuk mempelajari sesuatu, tidak mudah menyerah, dan terus berusaha untuk meningkatkan prestasinya (Dewi et al., 2019).Terdapat dua jenis motivasi belajar, pertama motivasi belajar intrinsik yang muncul tanpa dibutuhkannya rangsangan dari luar, tetapi dikarenakan siswa memerlukan ilmu yang telah dipelajarinya. Kedua motivasi belajar ekstrinsik yang timbul oleh rangsangan dari luar, dimana tujuan siswa belajar karena ingin mendapatkan angka yang tinggi, memperoleh gelar, dan hal lainnya, dimana pencapaian-pencapaian tersebut terletak diluar hal yang dipelajarinya (Haq Azhar, 2018).Kedudukan motivasi belajar begitu penting. Minimnya motivasi yang bersifat internal maupun eksternal dapat mengakibatkan rendahnya semangat siswa untuk mempelajari materi-materi pelajaran(Harianti, 2016).

Kondisi pandemi yang mengharuskan siswa belajar dirumah berdampak pada sulitnya siswa belajar dan menjadi penyebab menurunya minat belajar. Bagaimanapun dampak dari teknologi pada pembelajaran seperti pembelajaran daring dengan pemanfaatan aplikasi-aplikasi yang mendukung (Zoom Meaating, Google Meet, WhatsApp dll) dapat bernilai positif dan bahkan ada pula yang negatif. Semuanya membawa perubahan yang begitu cepat pada peserta didik.Efek dari bentuk perubahanitulah yangmenarik untuk dikaji secara mendalam dan sistematis melalui telaah aksiologi dalam tulisanini.Karenaitu, penulismemberi

judulpenelitianinidengantajuk"Pembelajaran Daring Di Era Pandemic Dalam Kajian Aksiologi"

\section{METODE}

Artikel ini membahas tentang analisis Aksiologi dalam pembelajaran daring, jenis metode penelitian ini adalah analisis kajian pustaka (literatur research) dari beberapa sumber yang relevan.Referensi teori yang diperoleh melalui penelitian studi literatur dijadikan sebagai alat utama maupun fondasi dasar bagi praktek penelitian di tengah lapangan.

Adapun ada metode pengumpulan data yang digunakan dalam penelitian ini adalah dokumentasi maupun studi literatur.Jenis data yang digunakan adalah data sekunder, yaitu data pendukung yang bersumber dari literatur maupun referensireferensi yang ada.Selain itu, dilakukan juga pengumpulan dokumen atau data-data yang dianggap penting untuk keperluan penelitian. 
Available online at http://jurnal.goretanpena.com/index.php/JSSR

\section{HASIL DAN PEMBAHASAN \\ Terminologi Aksiologi}

Kata aksiologi secara bahasa berasal dari kata Yunani, axion; nilai dan logos; ilmu, yang berarti teori tentang nilai (value). Pertanyaan masalah ini menyangkut antara lain: untuk apa pengetahuan ilmu ini digunakan? Bagaimana kaitan antara cara penggunaannya dengan kaidah-kaidah moral? Bagaimana kaitan metode ilmiah yang digunakan dengan norma-norma moral dan profesianal (Vardiansyah D dalam SanprayogiM, Chaer T, 2017) Aksiologi memuat pemikiran tentang masalah nilainilai termasuk nilai-nilai moral, agama, dan nilai keindahan.

Aksiologi bisa disebut sebagai the theory of value atau teori nilai. Bagian dari filsafat yang menaruh perhatian tentang baik dan buruk (good and bad), benar dan salah (right and wrong), serta tentang cara dan tujuan (means and ends). Dari lima komponen dalam pendidikan (tujuan pendidikan, pendidik dan tenaga pendidikan, peserta didik dan alat-alat pendidikan dan lingkungan atau konteks pendidikan.(Moh. Wardi, 2013).

Perkembangan ilmu pengetahuan mau tidak mau akan dibarengi dengan perkembangan bidang filsafat, karena keseimbangan antara ilmu pengetahuan dan filsafat akan menjadi sarana pengontrol aksiologi (nilai) ilmiah, yang akan mengantarkan pada peradaban manusia yang sama berharganya. Berdasarkan pengertian menurut bahasa sebagaimana tersebut di atas, maka penegertian aksiologi secara istilah adalah merupakan studi yang berkaitan dengan teori tentang nilai atau studi segala sesuatu yang dapat bernilai atau memberikan manfaat.Nilai merupakan suatu fenomena tapi tidak berada dalam suatu ruang dan waktu.Selain itu, nilai juga merupakan esensi-esensi logis dan dapat dipahami melalui akal.Selanjutnya, aksiologis dalam wacana filsafat mengacu pada persoalan etika (moral) dan estetika (keindahan)(Zaprulkhan, 2016).

Menurut UU No. 20 Tahun 2003

tentang Sistem Pendidikan

Nasional,pendidikan adalah sebuah usaha sadar dan terencana untuk mewujudkan suasana belajar dan proses pembelajaran agar peserta didik secara aktif mengembangkan potensi dirinya untuk memiliki kekuatan spiritual keagamaan, pengendalian diri, kepribadian, kecerdasan, akhlak mulia, serta keterampilan yang diperlukan dirinya, masyarakat, bangsa dan negara. Pendidikan menurut pengertian ini berarti juga menginginkan siswa memiliki etika dan estetika dalam memanifestasikan dirinya sendiri atau dalam kehidupan di masyarakat. Dalam bahasa lain siswa diharapkan memiliki seni dalam berpikir dan bertindak.)

\section{Pembelajaran Daring}

Dalam filsafat, penerapan ilmu berupa teknologi berkaitan erat dengan aksiologi keilmuan.Aksiologi keilmuan ini diartikan sebagai sesuatu yang berkaitan dengan kegunaan ilmu pengetahuan yang diperoleh (Firman, 2018).Sebagaicontoh, penggunaan teknologi berupa pembelajaran daring telah menyebabkan menurunnya minat belajar peserta didik.Berbeda dengan pembelajaran saat tatap muka aspek-aspek afektif masih dapat terukur dan terlihat.Padahal hakikat pengembangan ilmu pengetahuan itu bertujuan untuk membantu mencapai kesejahteraan umat manusia.

Dimasa pandemi pembelajaran daring menjadi upaya yang dilakukan pemerintah untuk tetap menjalankan proses pendidikan pada semua jenjang pendidikan formal sebagai adaptasi adanya pandemicCOVID19(Kemendikbud, 2020).Jauh sebelum masa pandemi COVID-19 pembelajarandaring sudah dikenal. Ini merupakan sebuah inovasi untuk memudahkan siswa menerima materi pembelajaran yang dapat diakses dengan internet, namun daring ini mempunyai keterbatasan akses internet dan perangkat yang digunakan menjadi penyebab tidak maksimal dalam penggunaannya ( $\mathrm{C}$ et al., 2013).

Pembelajaran daring merupakan pendidikan formal berbasis institusi atau lembaga yang membutuhkan media 
Available online at http://jurnal.goretanpena.com/index.php/JSSR

komunikasi interaktif agar dapat menghubungkan guru dan siswa serta berbagai sumber daya yang diperlukan (Nurhayati \& Purwanto, 2021). Dengan demikian, untuk menuntut ilmu, siswa tidak perlu hadir di ruang kelas, tetapi sudah dapat terhubung dengan guru dan teman-teman kelasnya melalui smartphone, laptop, ataupun komputer yang terkoneksi jaringan internet. (Bishara, 2018)

Model pembelajaran berbasis daring ini diberlakukan dengan transisi waktu yang singkat sehingga memberikan social shock tidak hanya bagi peserta didik tetapi juga bagi guru.Sehingga ditemukan bahwa dalam pembelajaran daring guru mengalami kesulitan untuk mengontrol seluruh siswa. Oleh karena itu, proses pembelajaran harus didukung dengan nilai kedisiplinandari peserta didik maupun guru (Gusdernawati et al., 2021).

Pembelajaran daring yang muncul secara tiba-tiba ini secara tidak langsung berdampak pada prestasi siswa. Pada masa pandemi dan dalam proses pembelajaran daring Faktor internal sangat penting untuk meningkatkan prestasi belajar peserta didik karena kemampuan peserta didik dalam menciptakan proses belajar dalam dirinya termasuk faktor pendukung prestasidan sudah tentuproses belajar dapat terjadi ketika peserta didik sendiri memiliki kesiapan belajar yang baik (Barutu et al., 2020).

Sebagian besar peserta didik mengungkapkan belajar secara luring lebih efektif dan memotivasi daripada belajar secara daring (Adnan, 2020). Meskipun pembelajaran daring mampu membantu menjaga kesehatan siswa saat pandemi COVID-19, tetapi tidak seefektif pembelajaran tatap muka, selain penyampaian materi yang mungkin saja terkendala oleh buruknya jaringan internet, interaksi antara peserta didik dengan guru dan teman-temannya menjadi berkurang. Sehingga, hal tersebut mungkin saja berdampak terhadap menurunnya motivasi belajar siswa. (Nurfallah \& Pradipta, 2021).
Penurunan motivasi belajar ini tentu akan berpengaruh pada prestasi belajar siswa. (Sintema, 2020) mengungkapkan bahwa COVID-19 berdampak terhadap kinerja peserta didik di sekolahdan dampak ini sangat dirasakan saat peserta didik akan mengikuti ujian. Senada dengan pernyataan ini (Gusdernawati et al., 2021) juga mengungkapkan, berbagai macam peraturan telah ditetapkan sekolah agar pelaksanaan ujian terlaksana dengan maksimal tanpa adanya indikasi kecurangan dalam pengisian jawaban. Tetapi, keadaan yang ditemukan di lapangan berbeda. Siswa memiliki banyak cara dalam menjawab soal ujian dan mengambil kesempatan untuk mendapatkan nilai yang baiksehingga pembelajaran daring telahmenimbulkanproblematikadalampenge mbangan kreatifitas siswa.

\section{Problematika Pembelajaran Daring}

Pelaksanaan pembelajaran daring yang dihitung baru bagi peserta didik terutama yang tinggal didaerah kecil tentu menemui problematika.Ada dua hal yang menyebabkan terjadinya pembelajaran yang tidak efektif selama pandemi yaitu;Pertama, pengerjaan tugas tidak terpantau langsung oleh guru.Kedua, beban tugas yang diberikan guru kepada siswa terlalu banyak, sehingga pembagian waktu tidak maksimal dan justru tugas lebih banyak mendapat bantuan dari orang lain.(Gusdernawati et al., 2021).

Problematika lain yang terjadi dalam proses pembelajaran daring adalah:

1. Peserta didik merasa sulit untuk memahami materi pembelajaran yang disampaikan oleh guru.

2. Peserta didiktidakmerasa termotivasi untuk belajar.

3. Pesertadidiktidakmeguasaipembelajaran dengan baik.

Hasil penelitian deskriptif yang ditulis oleh(Izzah et al., 2020) menggambarkan bahwa peserta didik paling banyak menyukai model pembelajaran secara tatap muka yaitu sebanyak $58.5 \%$ atau 31 orang peserta didik.Mereka menyukai tatap muka dikarenakan tatap muka lebih jelas, bisa 
Available online at http://jurnal.goretanpena.com/index.php/JSSR

lebih fokus, lebih mudah memahaminya, lebih mudah untuk bertanya ketika ada yang belum dimengerti.Selanjutnya ada 15 orang peserta didik atau $28,3 \%$ yang lebih menyukai model pembelajaran secara daring dikarenakan lebih fokus.

Tidak dapat dipungkiri pembelajaran dengan tatap muka masih tetap menjadi model pembelajaran yang paling disukai. Adapunkendala lain yang mereka rasakan adalah:

1. Banyak yang belum paham penggunaan aplikasi belajar yang digunakan.

2. Tidak ada kuota.

3. Handphone kurang mendukung.

4. Memori handphone yang penuh

5. Tidak mempunyai handphone. Terakhir

6. Jaringan internet kurang stabil. (Izzah, dkk. 2020)

Media pembelajaran yang dapat digunakan dalam pembelajaran online selama masa pandemi COVID-19 juga sangat mendukung untuk meningkatkan pemahaman dan keaktifan siswa dalam mengikuti pembelajaran daring. Pembelajaran matematika menjadi efektif apabila tersedia video pembelajaran yang berisi penjelasan materi secara rinci sehingga dapat diputar kembali jika siswabelum memahami materi.Kemudian tersedianya sesi tanya jawab/diskusi yang dilakukan melalui WhatsApp atau Google Classroom(Kusumaningrum \& Wijayanto, 2020)

Ketika dikaitkan dengan dimensi aksiologis, maka terdapat problem pendidikan selama masa pandemi antara lain:

1. Tujuan pendidikan yang berorientasi pada nilai-nilai kehidupan kurang atau belum mampu menyiapkan generasi yang seimbang (memiliki nilai sekaligus mampu mengikuti perkembangan teknologi).

2. Pendidik dan tenaga pendidik kurang siap. Pendidik juga hanya disibukkan dengan hal-hal teknis seperti tunjangan honor, tunjangan fungsional dan tunjangan sertifikasi.
3. Peserta didik dalam menuntut ilmu selama darig cenderung mengesampingkan nilai-nilai disiplin, jujur, dan kreatif (Moh. Wardi, 2013)

Upayadalammengatasipermasalahan tersebut yaitu guru harus bisa mencari metode pembelajaran yanglain supayasiswadapat memahami materi yang disampaikan oleh guru sehingga peserta didik dapatmenguasai materi pembelajaranyang dilaksanakandenganbaik dan peserta didik juga dapat termotivasi untuk

belajarwalaupunpembelajarandilakukan dengan cara daring(Fadilla et al., 2021). Guru perlu memasukkan nilai estetika dalam mengolah media pembelajaran sehingga pembelajaran menjadi menarik.

\section{PandanganAksiologiTerhadapPembelaja ran Daring}

Adanya pembatasan sosial pada era pandemi COVID-19 ini membuat komunikasi antar siswa dan guru menjadi terbatas.Diungkapkan jika pada pembelajaran daring ini diharapkan peserta didik tetap konsisten berpadu dengan keseluruhan nilai-nilai aksiologi sehingga pembelajaran yang dilakukan akan mendapatkan hasil yang maksimal.Di analisis dari pernyataan ini dapat dilihat bahwa pembelajaran daring harus tetap mengedepankan pengembangan nilai kreatifitas atau keterampilan selama proses pembelajaran daring berlangsung. Pernyataan ini didukung oleh (Gusdernawati et al., 2021) yang mengatakan pentingnya menerapapkan nilai aksiologi saat pembelajaran dikarenakan melalui pembelajaran serta pendidikan, mampu menjadi pembentuk kepribadian untuk memperluas pengetahuan danketerampilan yang akan mempengaruhikehidupan.

Selain konteks etika profetik, aksiologis dalam pendidikan meliputi estetika yang merupakan nilai-nilai yang berkaitan dengan kreasi yang berhubungan dengan seni. Namun, lebih jauh dari itu, maka dalam dunia pendidikan hendaklah nilai estetika menjadi patokan penting dalam 
Available online at http://jurnal.goretanpena.com/index.php/JSSR

proses pengembangan pendidikan yakni dengan menggunakan pendekatan estetismoral. Ini berarti pendidikandiorientasikan pada upaya menciptakan suatu kepribadian yang kreatif, berseni sehingga pendidikan tetap memiliki daya tarik dan kajian yang senantiasa berkesinambungan serta relevan(Moh. Wardi, 2013).

Pembelajaran diharapkan menjadi wadah dalam proses pertukaran ilmu yang sehat yang sesuai dengan nilai-nilai yang harus diperoleh dalam tujuan belajar. Pembentukan sikap dalam proses pembelajaran adalah hal utama agar peserta didik memiliki bekal untuk mengembangkan kehidupannya. Penggunaan teknologi dan berbagai aplikasi berbasis teknologi dalam pembelajaran daring sangat mempengaruhi proses interaksi antara pendidik, peserta didik, sumber belajar, dan media pembelajaran.

Dalam proses pembelajaran daring seperti ini dan jika dikaitkan dengan kajian aksiologi masih sedikit terlihat bahwa pembelajaran daring ini menambah manfaat. Malah dalam beberapa literatur ditemukan bahwa pembelajaran daring masih mengalami problematika, menimbulkan sikap yang negatif pada peserta didik yang diakibatkan tidak adanya pantauan langsung dari guru atau pendidik. Jika dianalisis dari beberapa sumber yang sudah dijelaskan diatas maka dapat dilihat bahwa pembelajaran daring sangat berdampak pada nilai dan moral para peserta didik.

\section{SIMPULAN}

Masa pandemi menjadi tantangan bagi seluruh sektor terutama pendidikan.Pendidikan memilikitugas yang cukup berat karena pembelajaran dilaksanakan secara tidak langsung, sehingga sulit bagi pendidik untuk melihat perkembangan nilai etika dari peserta didik. Dalam kajian aksiologi dalam pembelajaran daring maka nilai etika dan estetika menjadi hal yang wajib diperbincangkan. Nilai etika dan estetika dapat diamati melalui sikap yang ditunjukkan peserta didik selama pembelajaran daring berlangsung. Tampak bahwa selama pembelajaran daring dilaksanakan sikap dan perilaku peserta didik belum memunculkan kemandirian belajar. Kebanyakan peserta didik hanya mengikuti pembelajaran daring akibat dari adanya perintah dan paksaan (belum lahir dari keinginannya pribadi untuk mendapatkan ilmu). Saran peneliti harapannya dalam melaksanakan pembelajaran daring peserta didik sudah memiliki motivasi internal untuk belajar secara mandiri tanpa ada perintah dan peserta didik dapat menghayatinya sebagai kewajiban yang harus di laksanakan. Selain itu, peserta didik selalu menempatkan perilaku jujur dalam setiap pelaksanaan pembelajaran daring.

DAFTAR PUSTAKA

Adnan, M. (2020). Online learning amid the COVID-19 pandemic: Students perspectives. Journal of Pedagogical Sociology and Psychology, 1(2), 4551.https://doi.org/10.33902/jpsp.20202 61309

Almanthari, A., Maulina, S., \& Bruce, S. (2020). Secondary School Mathematics Teachers ' Views on E-learning Implementation Barriers during the COVID-19 Pandemic: The Case of Indonesia. 16(7).

Anim, A., \& Mapilindo. (2020). ERSEPSI MAHASISWA PENDIDIKAN

MATEMATIKA TENTANG PEMBELAJARAN DARING SELAMA MASA LEARN FROM HOME (LFH) PANDEMIC COVID-19. V(1).

Barutu, S. E., Education, M., \& Info, A. (2020). the Achievement of Mathematics Learning in Squadrate and Square Roots of Round Numbers. $8(2), 52-57$.

Bishara, S. (2018). Active and traditional teaching, self-image, and motivation in learning math among pupils with learning disabilities. Cogent Education, 5(1). https://doi.org/10.1080/2331186X.201 8.1436123 
Available online at http://jurnal.goretanpena.com/index.php/JSSR

C, B. D., Amelia, A., Hasanah, U., \& Abdy Mahesha Putra, H. R. (2013). Analisis Keefektifan Pembelajaran Online di Masa Pandemi Covid-19. MATHEdunesa, 2(1).

Dewi, V. R., Syamsuri, S., \& Khaerunnisa, E. (2019). Karakteristik Motivasi Ekstrinsik Dan Intrinsik Siswa Smp Dalam Belajar Matematika. TIRTAMATH: Jurnal Penelitian Dan Pengajaran Matematika, 1(2), 116. https://doi.org/10.48181/tirtamath.v1i2 .7145

Fadilla, A. N., Relawati, A. S., \& Ratnaningsih, N. (2021). Jurnal jendela pendidikan. 01(02), 48-60.

Gusdernawati, A., Mahatmasari, P. Y., Suherman, W. S., Lituhayu, K., \& Umam, A. K. (2021). E-LEARNING DI ERA PANDEMI COVID-19: BAGAIMANA AKSIOLOGI HASIL BELAJAR PENDIDIKAN JASMANI. 3, 63-74.

https://doi.org/DOI:http://dx.doi.org/10 .31258/jope.2.2.63-74

Haq Azhar. (2018). Motivasi Belajar Dalam Meraih Prestasi. Jurnal Pendidikan Islam Victratina, 3(1), 193-214.

Harianti, R. (2016). Pola Asuh Orangtua Dan Lingkungan Pembelajaran Terhadap Motivasi Belajar Siswa. Curricula, 2(2), 20-30. https://doi.org/10.22216/jcc.v2i2.983

Izzah, L., Bahar, H., \& Yanti, W. (2020). Efektivitas Pembelajaran Matematika Daring Melalui Quantum E-Learning Pada Masa Pandemi Covid-19 Di SMK Grafika. Prosiding Seminar Nasional Penelitian ..., 1, 1-10. https://jurnal.umj.ac.id/index.php/semn aslit/article/view/8823

Kemendikbud. (2020). Pedoman Penyelenggaraan Belajar Dari Rumah Dalam Masa Darurat Penyebaran Corona Virus Disease (Covid-19). Surat Edaran Nomor 15 Tahun 2O2O, 021, 1-20.

Kusumaningrum, B., \& Wijayanto, Z. (2020). Apakah Pembelajaran Matematika Secara Daring Efektif?
(Studi Kasus pada Pembelajaran Selama Masa Pandemi Covid-19). Kreano, Jurnal Matematika KreatifInovatif, 11(2), 139-146. https://journal.unnes.ac.id/nju/index.ph $\mathrm{p} /$ kreano/article/view/25029

Moh. Wardi. (2013). Problematika Pendidikan Islam dan Solusi Alternatifnya (Perspektif Ontologis, Epistemologis dan Aksiologis). Tadris, $8(1)$.

Nurfallah, M., \& Pradipta, T. R. (2021). Motivasi Belajar Matematika Siswa Sekolah Menengah Selama Pembelajaran Daring di Masa Pandemi COVID-19. Jurnal Cendekia: Jurnal Pendidikan Matematika, 5(3), 24252437.

https://doi.org/10.31004/cendekia.v5i3. 752

Nurhayati, F. E., \& Purwanto, S. E. (2021). Analysis of the Mathematics Learning Motivation of Class XI IPA Students during the Covid-19 Pandemic. Edumatica: Jurnal Pendidikan Matematika, 11(01), 93-98.

Sosial, D. A. N. I., \& Sulistyawati, T. E. (2020). Perspektif Aksiologi Terhadap Penurunan Minat Belajar Anak di Masa Pandemi. 1, 33-43.

Theopilus, Y., Yogasara, T., Theresia, C., \& Octavia, J. R. (2020). Analisis Risiko Produk Alat Pelindung Diri (APD) Pencegah Penularan COVID-19 untuk Pekerja Informal di Indonesia. Jurnal Rekayasa Sistem Industri, 9(2), 115134. https://doi.org/10.26593/jrsi.v9i2.4002. 115-134 